\title{
Spatial variations of the Argentine hake (Merluccius hubbsi (Marini, 1933)) spawning shoals in the Patagonian area during a reproductive season
}

\author{
Variaciones espaciales de los cardúmenes desovantes de merluza común (Merluccius hubbsi \\ (Marini, 1933)) en el área de Patagonia durante una estación reproductiva \\ Gustavo J. Macchi ${ }^{1,2}$, Marcelo Pájaro ${ }^{2}$ and Claudia Dato ${ }^{2}$ \\ ${ }^{1}$ Consejo Nacional de Investigaciones Científicas y Técnicas (CONICET). Rivadavia 1917 (1033), Buenos Aires, Argentina \\ ${ }^{2}$ Instituto Nacional de Investigación y Desarrollo Pesquero (INIDEP). Paseo Victoria Ocampo No 1, CC. 175, Mar del Plata (7600), Argentina \\ gmacchi@inidep.edu.ar
}

\begin{abstract}
Resumen.- Se analizaron los desplazamientos de los cardúmenes de merluza común Merluccius hubbsi en el área de desove de Patagonia antes del comienzo de la puesta y durante una temporada reproductiva. Se describieron los cambios de abundancia, composición de sexos, estructura de tallas y localización de los desoves. Durante octubre y noviembre, los cardúmenes de merluza migraron desde aguas más profundas hacia la costa, aproximadamente a los $44^{\circ} \mathrm{S}$, donde tiene lugar la puesta en diciembre. Durante enero las principales agregaciones reproductivas permanecieron cerca de la costa (50 $\mathrm{m}$ de profundidad) pero desplazadas hacia el sur $\left(45^{\circ} \mathrm{S}\right)$; en febrero la intensidad del desove disminuyó y las hembras en post-puesta comenzaron a retornar a aguas más profundas. En general, este proceso fue completado primeramente por los desovantes más jóvenes (35-45 cm LT), los cuales tienen una temporada reproductiva más corta que las hembras de mayor edad. Los machos arribaron más temprano al área de puesta y permanecieron durante más tiempo que las hembras. Durante el período reproductivo se observaron variaciones espaciales en la proporción de sexos, que fueron atribuidas a: 1) segregación local producida por el comportamiento reproductivo de la merluza, donde varios machos se agrupan con una hembra al momento de la puesta, y 2) migración de hembras en postpuesta hacia aguas más profundas, lo cual origina mayor proporción de machos en las áreas costeras.
\end{abstract}

Palabras clave: Merlucciidae, Océano Atlántico sudoccidental, reproducción, migración

\begin{abstract}
Displacements of Argentine hake Merluccius hubbsi shoals in the spawning area of Patagonia before and during a reproductive season were analyzed. In particular, monthly changes in fish density, sex composition, size structure and spawning location were described for this stock. During October-November, hake shoals moved from deeper waters to the coast at about $44^{\circ} \mathrm{S}$, where spawning took place in December. During January the main reproductive aggregations stayed near the coast (50 m depth) but displaced to the southern area $\left(45^{\circ} \mathrm{S}\right)$; in February spawning activity diminished and spent females began to return to deeper waters. In general, this process was first completed by young spawners (35-45 cm TL), which have a breeding season shorter than the old females. We observed that males arrived at the spawning area first and remained there for a longer period than females. During the reproductive period skewed sex ratios in different sampling sites were observed. These differences in sex composition were attributable to: 1) local segregation produced by the reproductive behavior of hake, in which males form groups with a single female, and 2) migration of spent females to deeper waters, which causes male-biased samplings in coastal areas.
\end{abstract}

Key words: Merlucciidae, southwest Atlantic Ocean, reproduction, migration

\section{Introduction}

The reproductive activity of the Patagonian stock of Argentine hake (Merluccius hubbsi) occurs during spring and summer with a main peak in January (Macchi et al. 2004). Historically, spawning has taken place mainly in coastal waters off the Chubut province, in the area known as Isla Escondida $\left(43^{\circ} 30^{\prime}-44^{\circ} \mathrm{S}\right)$, where this species formed large schools (Ciechomski et al. 1983, Macchi et al. 2005). Since 1998, changes in the spatial pattern of hake spawning aggregations were observed, which were characterized by a decrease in the density of shoals and a movement of fish to deeper water, with a more scattered distribution. This variation was associated with high levels of fishing exploitation applied mainly in the early 1990s (Ehrlich et al. 2000). 
However, recent studies showed that changes in spatial location of spawners did not appear to negatively affect the recruitment of the Patagonian hake stock, at least during 2001 and 2002 (Macchi et al. 2005).

Different aspects as oocyte development, gonadal maturation, fecundity and spawning frequency of Argentine hake have been analyzed (Christiansen et al. 1986, Louge \& Christiansen 1993, Macchi et al. 2004), but information about reproductive behavior of this species is scarce. $M$. hubbsi is a batch spawner with relatively high egg production compared to other members of the Merlucciidae family (Macchi et al. 2004). Analysis of hake aggregations showed that this species formed skewed sex ratios during the reproductive season, characterized in general by malebiased schools in areas with a high proportion of spawning females (Pájaro et al. 2005). This variation in sex composition was associated with a reproductive behavior that involves male-competition during fertilization. Nevertheless, reproductive aggregations with a high proportion of females were recently observed in an offshore spawning ground (Dato 2006). For this reason, we hypothesize that differences in sex ratio within the reproductive area of Argentine hake in part may be attributable to the movement of postspawning females to deeper waters.

In the present paper, we study the displacements of the Argentine hake shoals in the spawning area of Patagonia, before and during a reproductive season. We analyze monthly changes in fish density, sex composition, size structure and spawning location of this fishing stock.

\section{Material and methods}

Samples of $M$. hubbsi were collected during five research surveys carried out between October 2004 and February 2005 in the north-Patagonian area (Fig. 1).

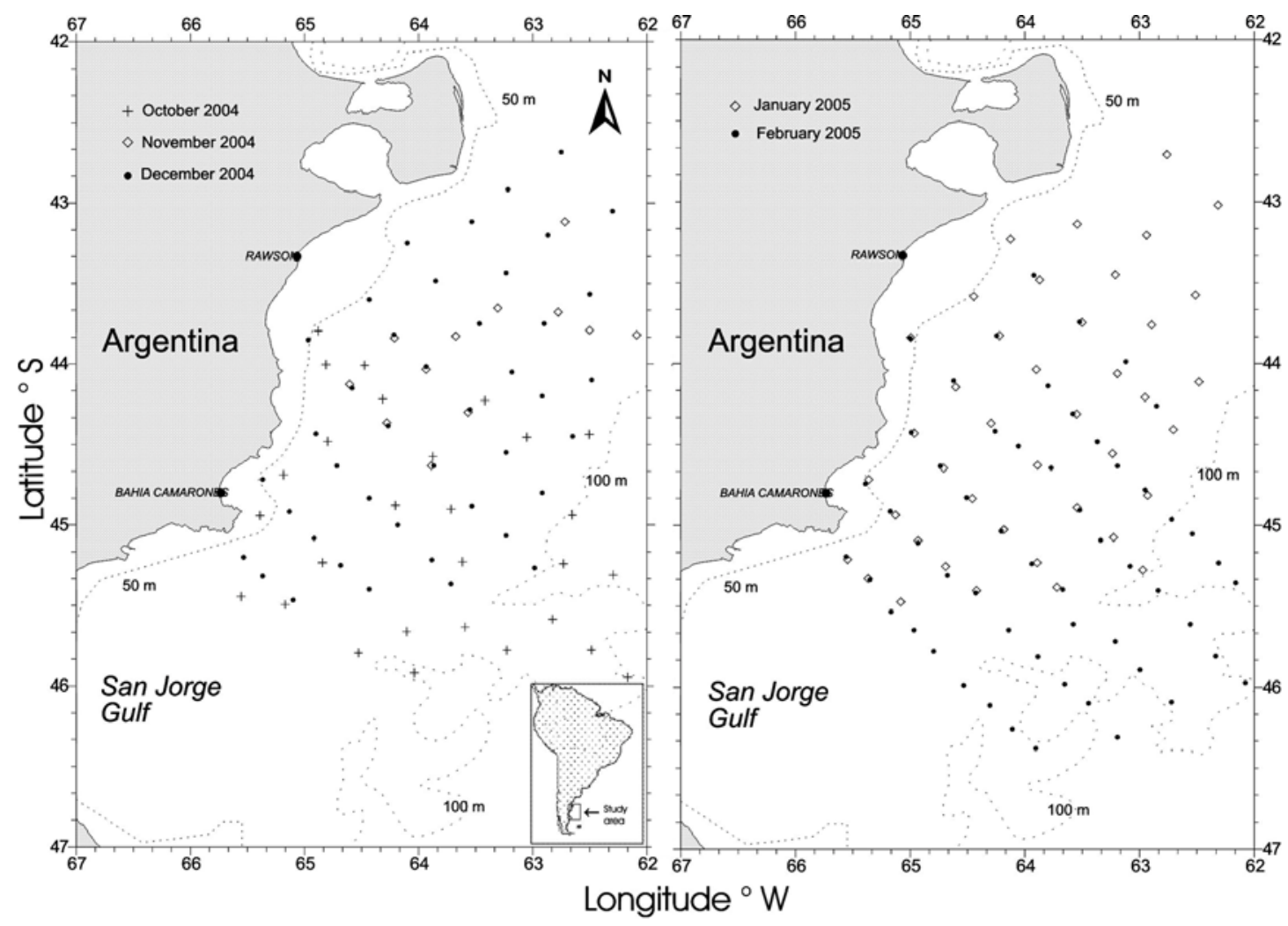

Figure 1

Samples location of Merluccius hubbsi collected from October 2004 to February 2005 in the north Patagonian area 
Argentine hake specimens were captured at depths between $50 \mathrm{~m}$ and $110 \mathrm{~m}$ using a bottom net with a mouth width of about $20 \mathrm{~m}$, a height of about $4 \mathrm{~m}$, and with a $20 \mathrm{~mm}$ mesh at the inner cover of the cod end. Total length (TL), sex and maturity stage were recorded for each fish sampled (Table 1). A macroscopic maturity key of five stages designed for biological studies was employed: 1) immature, 2) developing and partially spent, 3) spawning (gravid and running), 4) spent and 5) resting (Macchi \& Pájaro 2003). To validate this scale in females, 3778 paired ovaries were removed from individuals collected in different trawls (about 25-30 specimens per station) during the period analyzed (Table 1), and preserved in $10 \%$ formalin for histological analysis.

Ovaries were weighed (GW) to the nearest $0.1 \mathrm{~g}$ and a portion of sample (about $2.0 \mathrm{~g}$ ) was removed from each gonad, dehydrated in ethanol, cleared in xylol and embedded in paraffin. Sections were cut at 5$\mu \mathrm{m}$ thickness and stained with Harris's hematoxylin followed by eosin counterstain. Histological staging was based on the stage of oocyte development and on the occurrence of postovulatory follicles (POF) and atresia (Macchi et al. 2004), following the criteria previously described by Hunter \& Goldberg (1980) and Hunter et al. (1992). Postovulatory follicles were classified as day-0 (elapsed time from spawning $<24$ h) and day-1 (elapsed time from spawning $>24$ h but $<$ $48 \mathrm{~h}$ ), according to the description reported by Hunter \& Macewicz (1985a) for Engraulis mordax, which spawns at similar temperatures as $M$. hubbsi (Macchi \& Pájaro 2003). The criteria for identification of the different atresia stages and determination of postspawning condition of the ovary were adopted from Hunter \& Macewicz (1985b), who classified females with more than $50 \%$ vitellogenic alpha atresia as being spent.

To estimate length at first maturity $\left(\mathrm{L}_{50 \%}\right)$ a logistic model was fitted to the proportion of mature individuals (macroscopic stage 2 or higher) by total length class using the maximum likelihood method (Kendall \& Stuart 1967). Coefficients of the regression obtained for males and females, and from different months, were compared using a $\lambda^{2}$-test (Aubone \& Wöhler 2000).

Sex ratio (M:F) was determined as the number of males (M) divided by the number of females (F), only considering adult fish. This variable was estimated for each trawl station sampled during the period October 2004 - February 2005.

\section{Table 1}

Number of Argentine hake (Merluccius hubbsi) specimens sampled during the research surveys carried out in the north Patagonian area from October 2004 to February 2005

\begin{tabular}{|c|c|c|c|}
\hline Month & $\begin{array}{c}\text { Number of } \\
\text { trawls }\end{array}$ & $\begin{array}{c}\text { Number of } \\
\text { individuals } \\
\text { sampled }\end{array}$ & $\begin{array}{c}\text { Number } \\
\text { of ovaries } \\
\text { collected }\end{array}$ \\
\hline October 2004 & 27 & 18,508 & 52 \\
\hline November 2004 & 12 & 5,443 & 429 \\
\hline December 2004 & 42 & 10,274 & 1034 \\
\hline January 2005 & 55 & 10,467 & 1283 \\
\hline February 2005 & 41 & 11,562 & 980 \\
\hline
\end{tabular}

\section{Results}

\section{Hake abundance}

M. hubbsi abundance ( $\mathrm{t} \cdot$ nautical mile $\mathrm{e}^{-2}$ ) estimated from different trawl stations performed between October 2004 and February 2005 showed spatial variations during the spawning season (Fig. 2). At the beginning of this period (October 2004) the highest densities (100-300 t'nautical mile $\mathrm{e}^{-2}$ were observed at intermediate depth, between the $50 \mathrm{~m}$ and $100 \mathrm{~m}$ isobaths, from $44^{\circ}$ to $45^{\circ} \mathrm{S}$. One month later the most abundant shoals (200-400 $t$-nautical mile $\left.^{-2}\right)$ were detected near the coast between $44^{\circ}$ to $44^{\circ} 30^{\prime} \mathrm{S}$ (Fig. 2). During December, these fish schools (300-580 $\mathrm{t}$-nautical mile $^{-2}$ ) were sited at the same latitude as for November but inshore near the $50 \mathrm{~m}$ isobath. In January 2005 location of hake aggregations (500-750 $\mathrm{t}$-nautical $\mathrm{mile}^{-2}$ ) remained in the coast at $50 \mathrm{~m}$ depth, but displaced to the southern area in front of Bahía Camarones (between 44 $30^{\prime}$ and $45^{\circ} \mathrm{S}$ ). Later, in February, a decline in hake density was observed in all sampled area, with values lower than $50 \mathrm{t} \cdot$ nautical mile ${ }^{-2}$ (Fig. 2). 


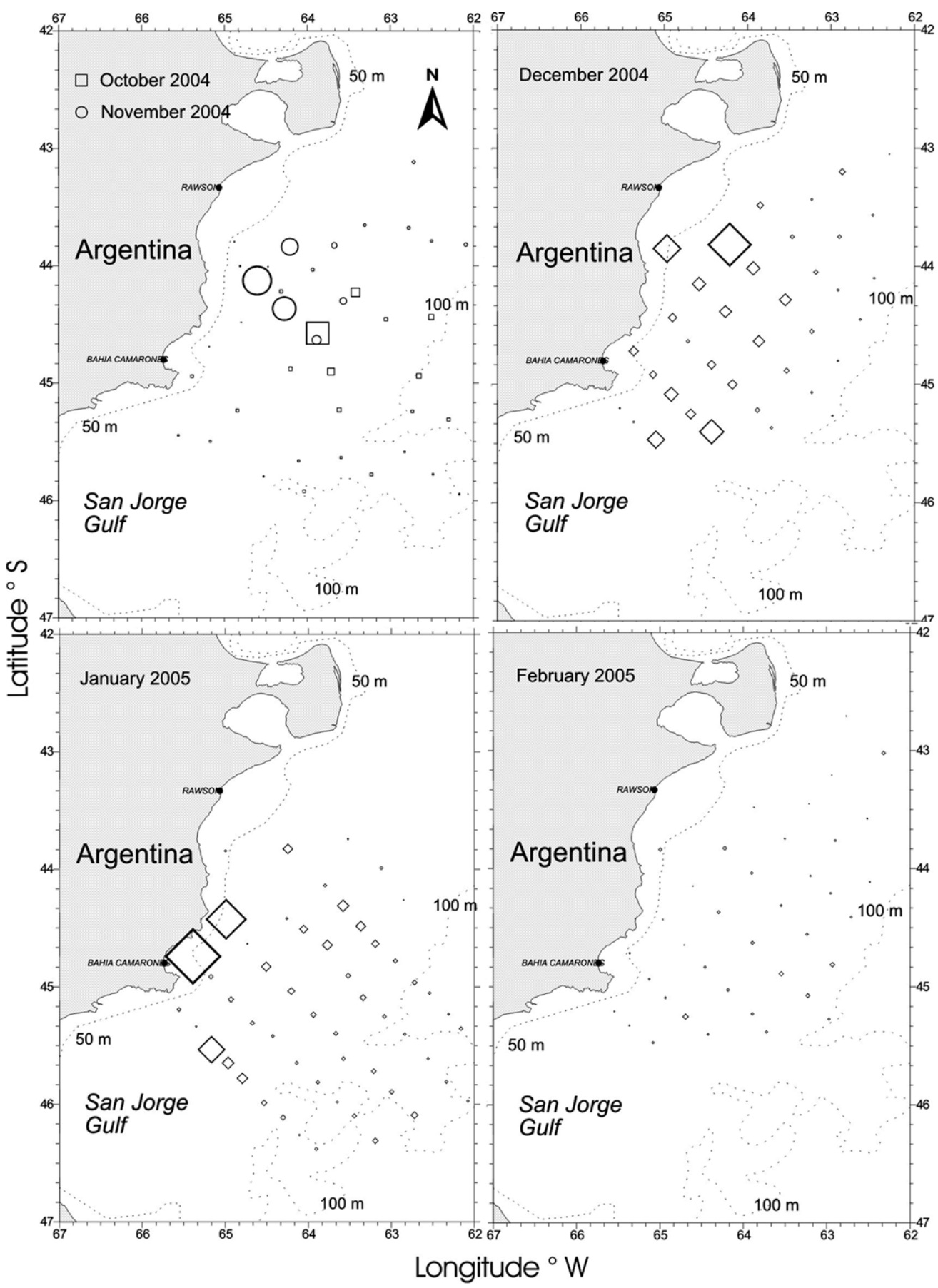

Figure 2

Spatial distribution of Merluccius hubbsi density values (t•nautical mile ${ }^{-2}$ ) estimated from trawl surveys carried out from October 2004 to February 2005 in the north-Patagonian area. The size of the symbols is proportional to the density values, which ranged between 0 and 750 t'nautical mile $^{-2}$

Distribución espacial de los valores de densidad de Merluccius hubbsi (t·milla náutica ${ }^{-2}$ ) estimados de cruceros de arrastre realizados desde octubre de 2004 a febrero de 2005 en el área nor-patagónica. El tamaño de los símbolos es proporcional a los valores de densidad, que varían entre 0 y 750 t·milla náutica ${ }^{-2}$ 


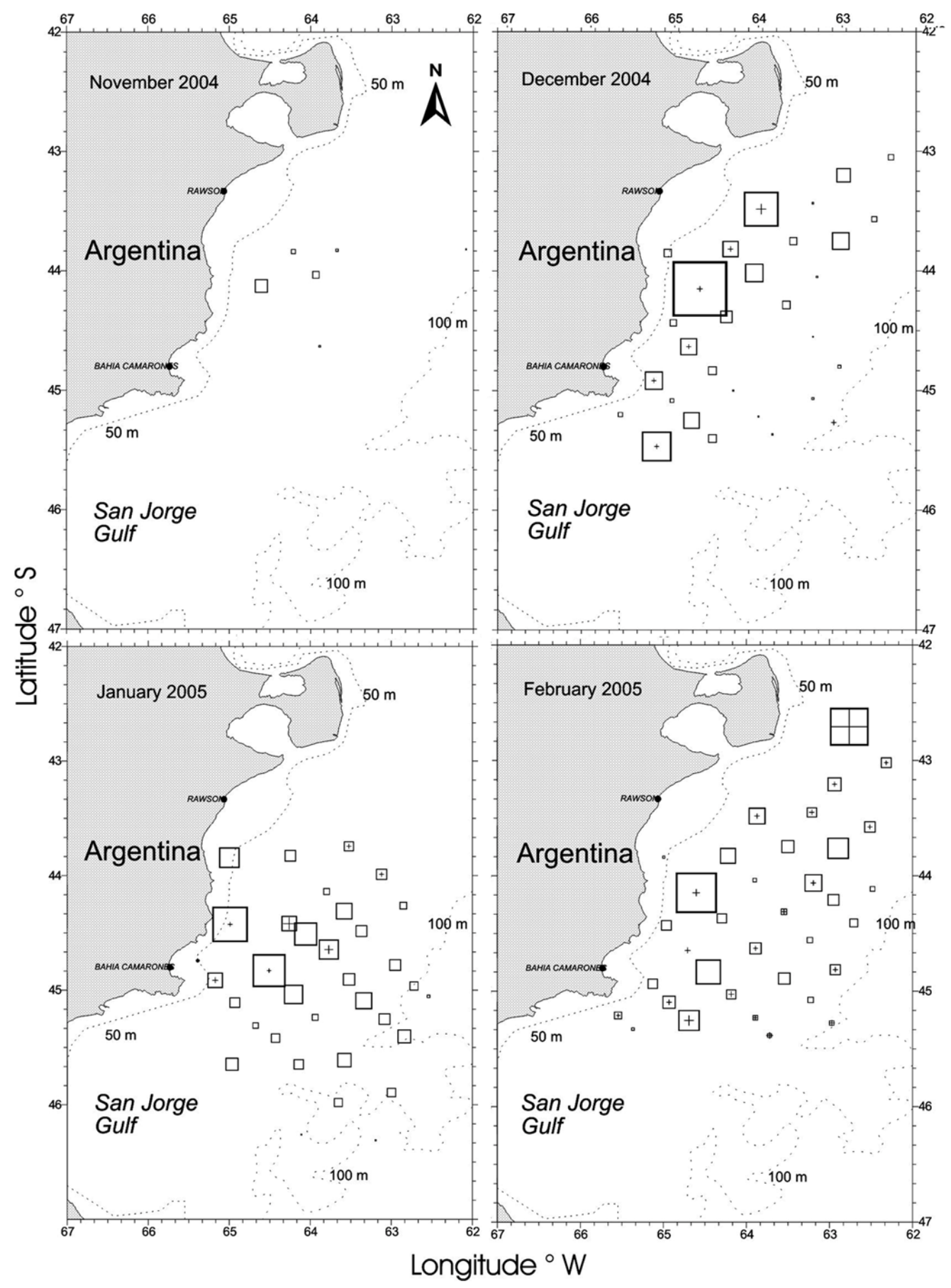

Figure 3

Spatial distribution of gravid (square) and spawning females (plus) of Merluccius hubbsi in the north-Patagonian area, from November 2004 to February 2005. The size of the symbols is proportional to the percentage of each stage, which ranged between 0 and $25 \%$

Distribución espacial de hembras grávidas (cuadrado) y en desove (cruz) de Merluccius hubbsi en el área nor-patagónica, desde noviembre de 2004 a febrero de 2005. El tamaño de los símbolos es proporcional al porcentaje de cada estadio, que varía entre 0 y $25 \%$ 


\section{Spawning areas}

To determine the main reproductive areas of Argentine hake in the Patagonian region during the period October 2004 - February 2005, we consider the proportion of gravid females (with hydrated oocytes) and spawning females (with day-0 POF) by trawl station. In general both criteria coincided, in areas with a high proportion of gravid females a high incidence of spawning individuals was observed (Fig. 3). Moreover, seasonal variation of spawning aggregations showed the same spatial pattern observed for the most abundant shoals of Argentine hake (Fig. 2).

During October 2004, no spawning individuals of M. hubbsi were detected in the Patagonian area. First evidence of oocyte hydration was observed in November, with low percentages of gravid females by trawl station $(<10 \%)$. These specimens were collected near the $44^{\circ} \mathrm{S}$ latitude, at $66-77 \mathrm{~m}$ depths (Fig. 3). During December 2004, reproductive activity of hake increased, with gravid and spawning females distributed from $43^{\circ}$ to $45^{\circ} 30^{\prime} \mathrm{S}$, between 60 and $85 \mathrm{~m}$ depth, but the highest percentages of gravid individuals were located inshore mainly in the northern area (Fig. 3). In January 2005, an expansion of the hake spawning area was observed, with gravid females distributed from the coast to the $100 \mathrm{~m}$ isobath. However, reproductive activity was most important in the southern area near Bahía Camarones (Fig. 3). During February 2005, spatial distribution of reproductive hake females was wider than in January, showing spawning individuals (with day-0 POF) in all sampled area (Fig. 3).

Analyzing the spatial distribution of post-spawning females during the reproductive period, we detected an increase of this stage as the breeding season progressed (Fig. 4). Nevertheless, in contrast to that observed with the gravid or spawning condition, spent females mainly dominated the offshore area at depths near the $100 \mathrm{~m}$ isobath. During February 2005, the post-spawning sector increased in area including intermediate depth waters between $80 \mathrm{~m}$ and $100 \mathrm{~m}$ (Fig. 4).

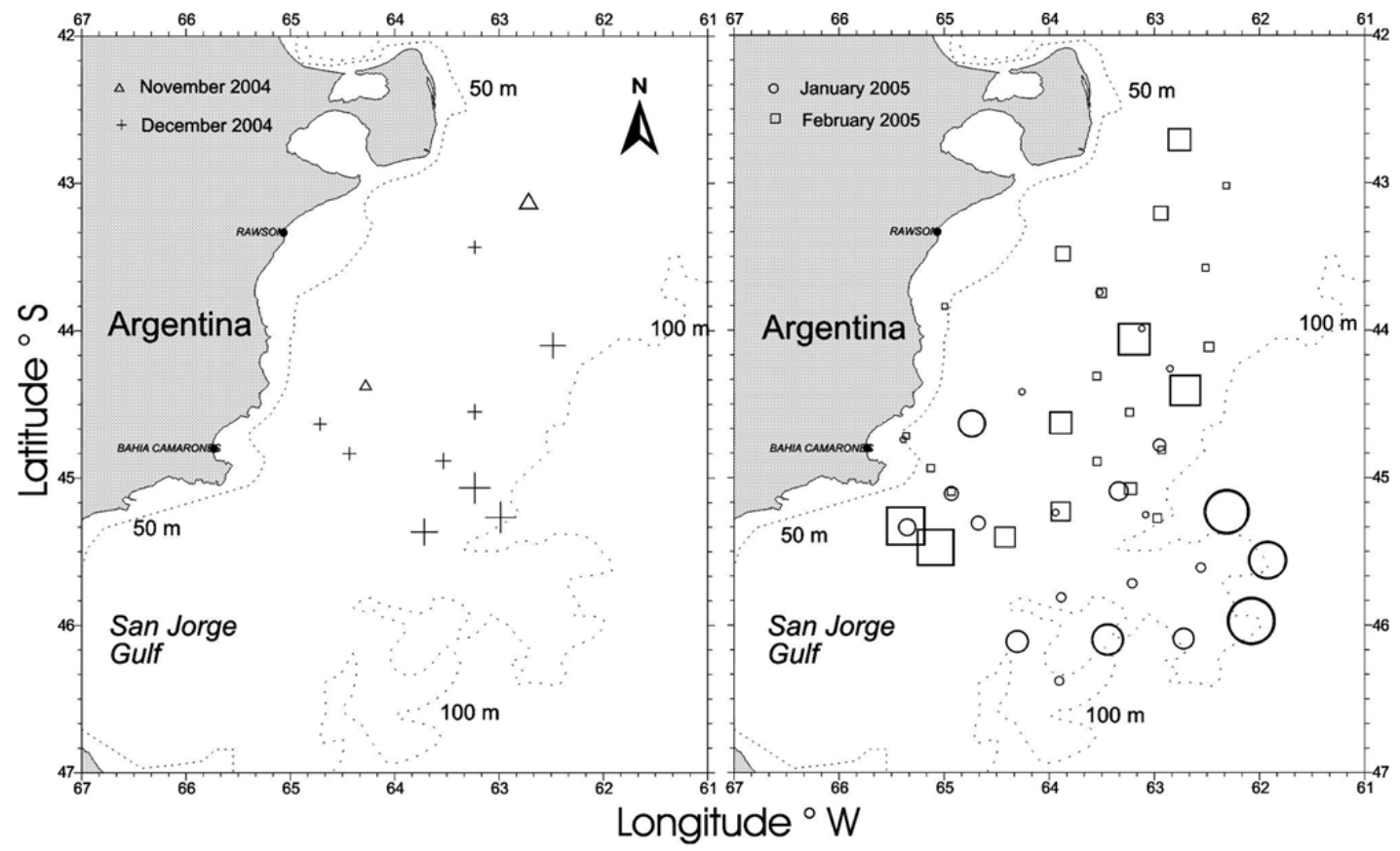

Figure 4

Spatial distribution of post-spawning females of Merluccius hubbsi in the north-Patagonian area, from November 2004 to February 2005. The size of the symbols is proportional to the percentage of this stage, which ranged between 0 and $20 \%$

Distribución espacial de hembras en postdesove de Merluccius hubbsi en el área nor-patagónica, desde noviembre de 2004 a febrero de 2005. El tamaño de los símbolos es proporcional al porcentaje de este estadio, que varía entre 0 y $20 \%$ 
Table 2

Coefficients of the logistic functions ( $\mathrm{L}_{50 \%}$ and slope b) obtained to estimate length at maturity (cm) in Merluccius hubbsi of
the Patagonian stock during the reproductive period October 2004 - February 2005

Coeficientes de las funciones logísticas ( $\mathrm{L}_{50 \%}$ y pendiente b) obtenidas para estimar la longitud de primera madurez (cm) de Merluccius hubbsi del efectivo patagónico durante el período reproductivo octubre 2004 - febrero 2005

\begin{tabular}{ccccccc}
\hline Month & \multicolumn{3}{c}{ Males } & & Females \\
& $\mathrm{L}_{50 \%}$ & $\mathrm{~b}$ & $n$ & $\mathrm{~L}_{50 \%}$ & $\mathrm{~b}$ & $n$ \\
\hline October 2004 & 29.28 & 0.4931 & 1212 & 31.71 & 0.4166 & 944 \\
November 2004 & 29.77 & 0.5086 & 3354 & 35.01 & 0.5285 & 2082 \\
December 2004 & 27.04 & 0.5841 & 5472 & 34.82 & 0.6287 & 4782 \\
January 2005 & 27.29 & 0.7256 & 6674 & 32.95 & 0.8546 & 3772 \\
February 2005 & 26.98 & 0.7470 & 8324 & 32.34 & 0.7866 & 3213 \\
\hline
\end{tabular}

\section{Size at maturity}

Length at first maturity ( $\mathrm{L}_{50 \%}$ ) estimated for males of Argentine hake in different months of the period October 2004 - February 2005 ranged between $27.0 \mathrm{~cm}$ TL and $29.8 \mathrm{~cm}$ TL (Table 2). In the case of females $\mathrm{L}_{50 \%}$ values were significantly higher $(P<0.01)$ than those obtained for males of the same month and ranged between $31.7 \mathrm{~cm}$ and $35.0 \mathrm{~cm}$ TL (Table 2). Comparison of this variable for individuals of the same sex, but sampled in different months of the reproductive season, also showed significant differences $(P<0.01)$. The $\mathrm{L}_{50 \%}$ value estimated for all sampled period (October 2004 - February 2005) was $27.7 \mathrm{~cm}$ TL for males and $33.8 \mathrm{~cm}$ TL for females.

\section{Length distributions and sex ratio}

Figure 5 shows the length-frequency distributions obtained for males and females during different months of the reproductive period analyzed. Juveniles of both sexes dominated in October 2004 with a main mode at $26 \mathrm{~cm} \mathrm{TL}$, but in the case of males a second mode of adult fish at $38 \mathrm{~cm}$ TL was observed. In November, this last group became principal for males; for females juveniles continued dominating in the samples, but another group corresponding to adult individuals with a mode at $44 \mathrm{~cm}$ was observed (Fig. 5). During December, size-frequency distribution for males basically did not change, but females showed and increase in adult proportion respect to November, with a main mode in $40 \mathrm{~cm}$ TL and two secondary modes in $26 \mathrm{~cm} \mathrm{TL}$ and $18 \mathrm{~cm}$ TL (Fig. 5). During January and February 2005, length distributions for males and females were basically composed by adult specimens, with modes between 36 and $40 \mathrm{~cm}$ TL (Fig. 5). In general, a decline in female proportion was observed for both months in comparison with December 2004. During February, this decrease was more important than in January, mainly in young females between 35 $\mathrm{cm}$ and $45 \mathrm{~cm}$ TL (Fig. 5).

Spatial distribution of the sex ratio (M:F) showed considerable variation during the spawning season (Fig. 6). In October 2004, sex ratio was about one for all sampled area showing similar proportions of males and females, except in those stations with high hake densities, where males dominated the samplings sites $(\mathrm{M}: \mathrm{F}=2-3)$. During November, male proportion increased mainly in the coastal area between $44^{\circ}$ and $44^{\circ} 30^{\prime} \mathrm{S}$, in coincidence with the location of gravid females (Fig. 6). The same pattern was observed in December and January, with high proportions of males mainly in those sites where females were gravid or in spawning stage $(\mathrm{M}: \mathrm{F}=5-6)$. During February, males dominated all the area from $42^{\circ} 30^{\prime} \mathrm{S}$ to $46^{\circ} \mathrm{S}$, but the highest M:F values (10-13) were observed inshore, mainly south of the $44^{\circ} \mathrm{S}$ latitude in front of Bahía Camarones (Fig. 6).

\section{Discussion}

Previous studies based on abundance of Argentine hake, eggs in plankton samples showed that reproductive activity of the Patagonian stock begins between November and December (Ehrlich \& Ciechomski 1994). Other authors analyzing the egg production during one breeding season (December 2000 - March 2001) suggested the beginning of 


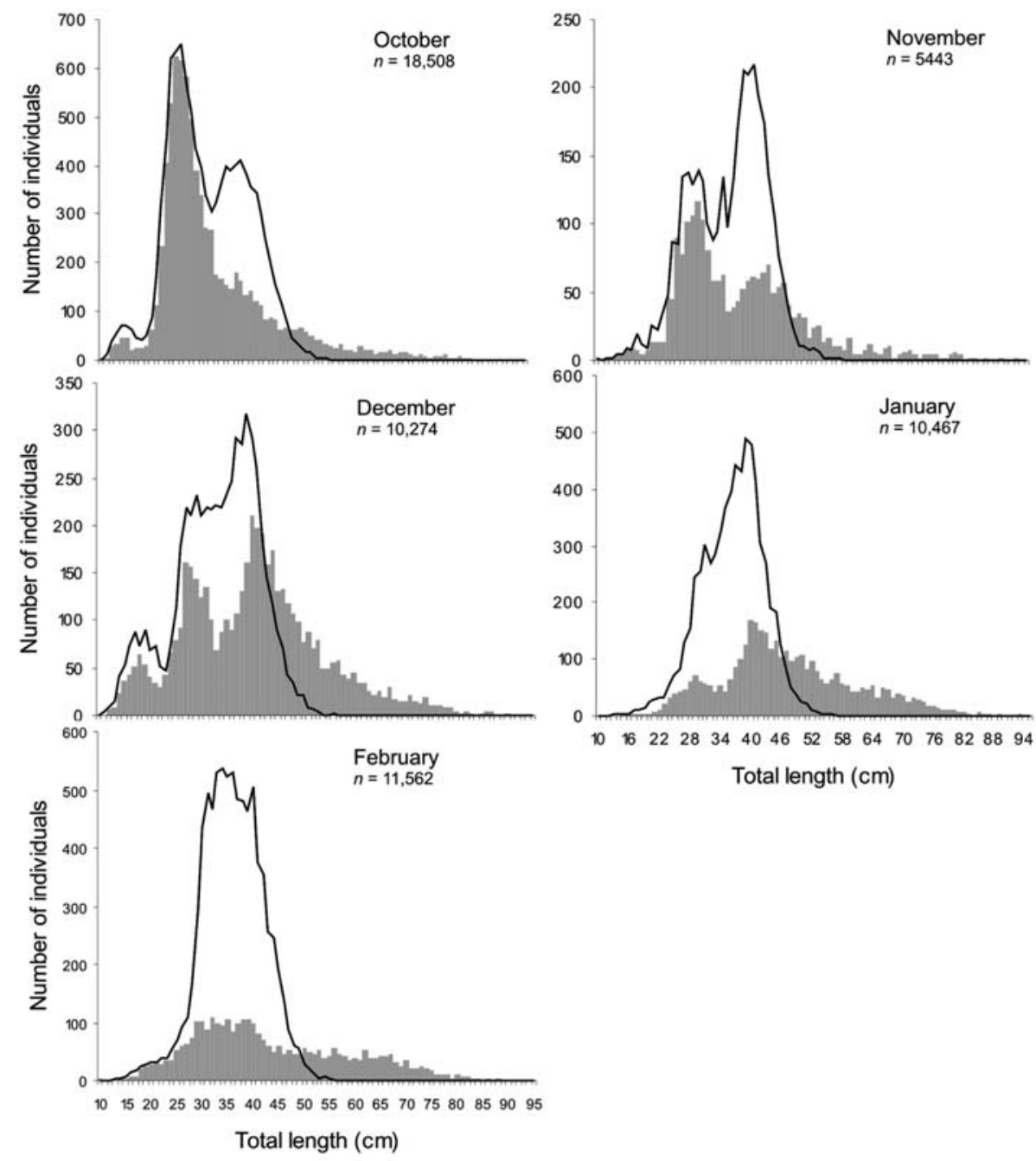

Figure 5

Length frequency distributions obtained for males (line) and females (gray bars) of Merluccius hubbsi in the northPatagonian area from October 2004 to February 2005

Distribuciones de frecuencia de talla obtenidas para machos (línea) y hembras (barras grises) de Merluccius hubbsi en el área norpatagónica desde octubre de 2004 a febrero de 2005

spawning in November for this stock, but no samples were obtained in that month (Macchi et al. 2004). During the reproductive period 2004-2005, it was possible to collect samples of $M$. hubbsi in October and November, and to determine that the first gravid females start to appear during November but in low proportions.
Spatial distribution of hake aggregations in the north-Patagonian area $\left(43^{\circ}-46^{\circ} \mathrm{S}\right)$ showed a movement of this species previous to the onset of spawning (October) from deeper waters (more than $100 \mathrm{~m}$ depth) toward the coast (near the $50 \mathrm{~m}$ isobath), where reproduction takes place. During 2004 this process began in November-December in the northern area $\left(44^{\circ} \mathrm{S}\right)$, and one month later the most abundant shoals moved to the south $\left(44^{\circ} 30^{\prime}-45^{\circ} \mathrm{S}\right)$ following the $50 \mathrm{~m}$ 


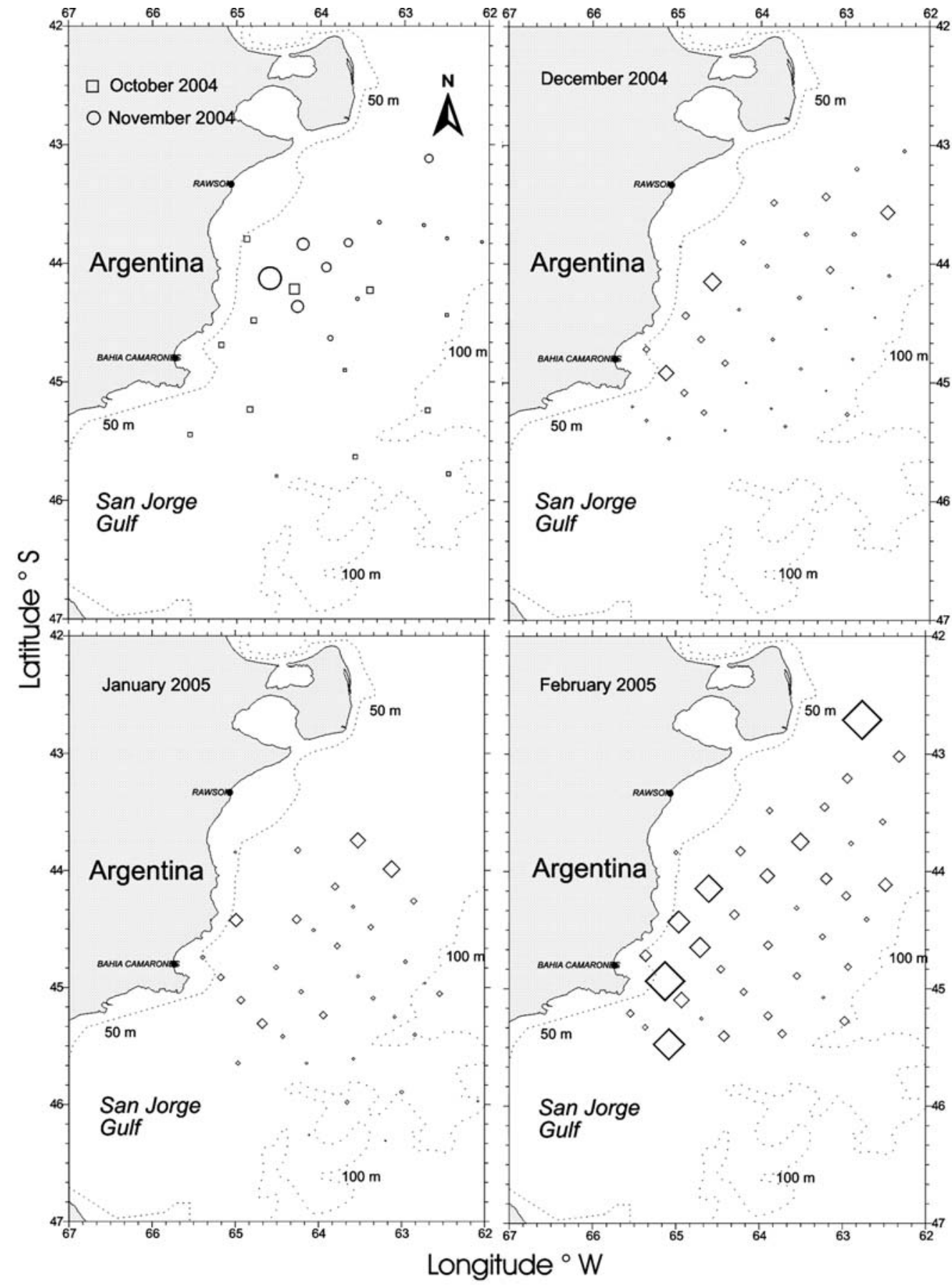

Figure 6

Spatial distribution of the sex ratio (M:F) obtained for Merluccius hubbsi in the north-Patagonian area from October 2004 to February 2005. The size of the symbols is proportional to the M:F values, which ranged between 0.40 and 13

Distribución espacial de la relación de sexos (M:F) obtenida para Merluccius hubbsi en el área nor-patagónica desde octubre de 2004 a febrero de 2005. El tamaño de los símbolos es proporcional a los valores de M:F, que varían entre 0.40 y 13 
isobath. During February 2005, density of hake decreased in the area as a consequence of displacements of this species offshore after spawning (Fig. 7). The movement from deeper waters to the coast observed in pre-spawning females is coincident with the hypothesis of a local stock of hake sited between $43^{\circ}$ and $48^{\circ} \mathrm{S}$, which stay in external platform waters during winter and later migrates for spawning (Perez Comas 1990). On the other hand, latitudinal displacement of spawning aggregations observed from December to January may be associated with the increases in water temperature during summer (Pájaro et al. 2005). The movement of fish toward deeper waters observed since February would be related to feeding, taking into account previous reports that mention full stomachs in post-spawning females collected offshore (Angelescu \& Prenski 1987).

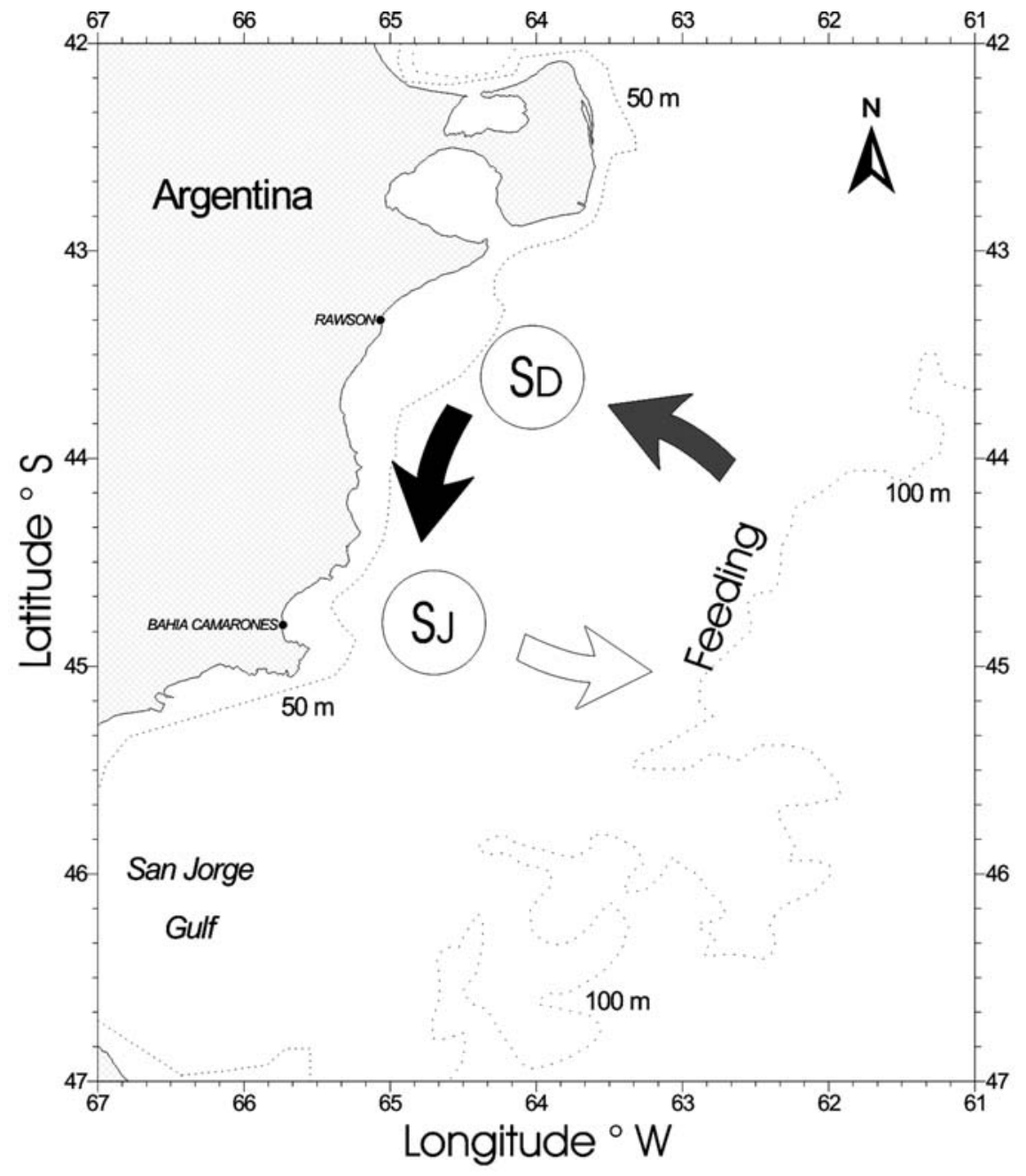

Figure 7

Spawning cycle of Merluccius hubbsi in the north-Patagonian area. The arrows represent different periods: OctoberNovember (gray), December-January (black) and February-March (white). The circles show the main spawning sites in December (SD) and January (SJ)

Ciclo de desove de Merluccius hubbsi en el área nor-patagónica. Las flechas representan diferentes períodos: octubre-noviembre (gris), diciembre-enero (negro) y febrero-marzo (blanco). Los círculos muestran las principales áreas de desove en diciembre (SD) y enero (SJ) 
In general, during the reproductive season 20042005 spawning aggregations of Argentine hake in Patagonian waters were spatially coincident with those described for this stock in previous years (Macchi et al. 2004, Pájaro et al. 2005), but during January and February 2005, a great dispersion of gravid females was observed. This new pattern showed an expansion of the hake spawning area toward deeper waters in comparison to that reported for January 2001 and 2004 (Macchi \& Pájaro 2005). This observation was corroborated during January 2006 (Dato 2006), and suggests that reproduction of the Patagonian hake stock could occur at temperatures lower than those previously reported for this species (Pájaro et al. 2005).

Length at maturity values for males during the reproductive period 2004-2005 were similar to those obtained in 2000-2001, but for females $L_{50 \%}$ was between 1 and $2 \mathrm{~cm}$ higher than that estimated for Argentine hake four years ago (Pájaro et al. 2005). Although the values obtained during 2004-2005 were much lower than those reported for this species in the 1980s (Simonazzi \& Otero 1986, Ruiz \& Fondacaro 1997), no decreasing in length at maturity for $M$. hubbsi was observed since the 2000s.

In October 2004, previous to the onset of spawning, hake aggregations showed a high proportion of juveniles in the north-Patagonian area, but between November 2004 and January 2005 these shoals consisted mainly of adult fish. In February, hake schools with high density values were not observed. Length distributions and sex ratio show variations during this reproductive period. During October, in addition with higher percentages of juveniles, sex ratio for adult hakes indicated similar proportion of males and females in most of the sampling sites. In November, at the beginning of spawning, the increase in male proportion suggests the arrival of this sex prior to females, as was previously mentioned for Argentine hake (Pájaro et al. 2005) and other species (Green et al. 1966, Eckman 1991, Morgan \& Trippel 1996). During December, female proportion in the north-Patagonian area was higher than in November, but male-biased sex ratio dominated in those sites with high percentages of spawning females. A similar pattern was observed in January, but one month later male-biased samplings covered all the area, mainly inshore with $\mathrm{M}: \mathrm{F}$ values higher than 10. This male concentration observed near the coast during February was consequence of the movement of females to deeper waters after spawning. Analysis of length distributions showed that decreasing in adult female proportion after reproductive peak occurred mainly in young specimens (between $35 \mathrm{~cm}$ and $45 \mathrm{~cm} \mathrm{TL}$ ), which in general have a spawning period shorter than old females (Macchi et al. 2004). The displacement of post-spawning females to the offshore area was evident by the increases of spent individuals in deeper waters near the end of the reproductive season. This behavior indicates that males remain in the spawning area for a longer period than females as reported Pájaro et al. (2005) for the same species.

Therefore, the skewed sex ratio observed in the spawning area of $M$. hubbsi may be attributable to two sources: 1) local segregation produced by some reproductive behavior as courtship, in which males form groups with a single female, as was suggested for other species (Hunter \& Goldberg 1980), 2) migration of post-spawning females to deeper waters, which causes male-biased samplings mainly in coastal areas.

We previously mentioned the expansion of the Argentine hake spawning to the offshore zone in Patagonia during January-February 2005 and January 2006. In contrast to that observed near the coast, reproductive activity in this external area in general was characterized by female-biased samplings. This observation could be explained in part by the second point mentioned above: the movement of spent females to deeper water, which may mask the possible local segregation caused by courtship.

\section{Acknowledgements}

We thank Teresa Carlé, Marta Estrada and Ernesto Christiansen for preparation of the histological sections. We also thank Stuart Anderson for reading and making suggestions to improve the manuscript. We would also like to thank two anonymous reviewers for a critical review of our manuscript. INIDEP Contribution $\mathrm{N}^{\circ} 1476$.

\section{Literature cited}

Angelescu V \& LB Prenski. 1987. Ecología trófica de la merluza común del mar argentino (Merluccidae, Merluccius hubbsi). II. Dinámica de la alimentación analizada sobre la base de las condiciones ambientales, la estructura y las evaluaciones de los efectivos en su área de distribución. Contribución INIDEP 561: 1-205.

Aubone A \& OC Wöhler. 2000. Aplicación del método de máxima verosimilitud a la estimación de parámetros y 
comparación de curvas de crecimiento de Von Bertalanffy. Informe Técnico Interno INIDEP 37: 1-21.

Christiansen E, PD Glorioso \& CE Olivieri. 1986. Aplicación de la histología en la determinación de efectivos de merluza (Merluccius hubbsi). Tipificación de tejidos, cálculos de fecundidad y vinculación con las condiciones ambientales. Publicación Comisión Técnica Mixta Frente Marítimo 1(2): 567-574.

Ciechomski JD, RP Sánchez, CA Lasta \& MD Ehrlich. 1983. Distribución de huevos y larvas de anchoíta (Engraulis anchoita) y de merluza (Merluccius hubbsi), evaluación de sus efectivos desovantes y análisis de los métodos empleados. Contribución Instituto Nacional de Investigación y Desarrollo Pesquero (Mar del Plata) 432: 3-37.

Dato C. 2006. Evaluación de abundancia de juveniles de merluza en la zona de cría norpatagónica. Informe Campaña EH-01/06, INIDEP: 1-16.

Eckmann R. 1991. A hydroacoustic study of the pelagic spawning behavior of whitefish (Coregonus lavaretus) in Lake Constance. Canadian Journal of Fisheries and Aquatic Science 48: 995-1002.

Ehrlich MD \& JD Ciechomski. 1994. Reseña sobre la distribución de larvas de merluza (Merluccius hubbsi) basada en veinte años de investigaciones. Publicación Comisión Técnica Mixta Frente Marítimo 15 (Sec.A): 3750.

Ehrlich MD, P Martos, A Madirolas \& RP Sánchez. 2000. Causes of spawning pattern variability of anchovy and hake on the Patagonian shelf. ICES Council Meeting 6: 1-13.

Green GH, TG Northcote, GF Hartman \& CC Lindsey. 1966. Life histories of two species of catostomid fishes in Sixteenmile Lake, British Columbia, with particular reference to inlet spawning. Journal of the Fisheries Research Board of Canada 23: 1761-1788.

Hunter JR \& SR Goldberg. 1980. Spawning incidence and batch fecundity in northern anchovy, Engraulis mordax. Fishery Bulletin 77(3): 641-652.

Hunter JR \& BJ Macewicz. 1985a. Measurement of spawning frequency in multiple spawning fishes. In: Lasker RM (ed), An egg production method for estimating spawning biomass of pelagics fish: Application to the northern anchovy, Engraulis mordax, NOAA Technical Report NMFS 36: 79-94.

Hunter JR \& BJ Macewicz. 1985b. Rates of atresia in the ovary of captive and wild northern anchovy, Engraulis mordax. Fishery Bulletin 83: 119-136.
Hunter JR, BJ Macewicz, NCH Lo \& CA Kimbrell. 1992. Fecundity, spawning, and maturity of female Dover sole Microstomus pacificus, with an evaluation of assumptions and precision. Fishery Bulletin 90: 101-128.

Kendall MG \& A Stuart. 1967. The Advance Theory of Statistics, 690 pp. Charles Griffin and Company Limited, Londres.

Louge EB \& HE Christiansen. 1993. Fecundidad de la merluza Merluccius hubbsi durante la temporada estival de 1988. Boletin Instituto Español Oceanografía 9 (2): 343-346.

Macchi GJ \& M Pájaro. 2003. Comparative reproductive biology of some commercial marine fishes from Argentina. Fisken og Havet 12: 69-77.

Macchi GJ \& M Pájaro. 2005. Distribución espacial, estructura de tallas y longitud de primera madurez de la merluza (Merluccius hubbsi) en el área de desove patagónica durante la temporada reproductiva 2004-2005. Informe Técnico Interno INIDEP 46: 1-15.

Macchi GJ, M Pájaro \& M Ehrlich. 2004. Seasonal egg production pattern of the Patagonian stock of Argentine hake (Merluccius hubbsi). Fisheries Research 67: 25-38.

Macchi GJ, M Pájaro \& A Madirolas. 2005. Can a change in the spawning pattern of Argentine hake (Merluccius hubbsi) affect its recruitment? Fishery Bulletin 103: 445452.

Morgan MJ \& EA Trippel. 1996. Skewed sex ratios in spawning shoals of Atlantic cod (Gadus morhua). ICES Journal of Marine Science 53: 820-826.

Pájaro M, GJ Macchi \& M Ehrlich. 2005. Reproductive pattern of the Patagonian stock of Argentine hake (Merluccius hubbsi). Fisheries Research 72: 97-108.

Pérez Comas JA. 1990. Biology and distribution of the Argentine hake (Merluccius hubbsi): considerations on its stock structure, migrations and dynamics of its nursery ground at San Jorge Gulf (Argentina). Ph D Thesis. University of Washington. School of Aquatic and Fishery Sciences, Seattle, 179 pp.

Ruiz AE \& RP Fondacaro. 1997. Talla de primera madurez de merluza (Merluccius hubbsi) en el área de Isla Escondida, Patagonia (diciembre 1989 - enero 1994). Naturalia Patagónica Ciencia Biológicas 5: 29-38.

Simonazzi MA \& HO Otero. 1986. Aspectos de la estructura de población de la merluza común (Merluccius hubbsi). I. Largo y edad de primera madurez, relación largo-peso. Publicación Comisión Técnica Mixta Frente Marítimo 1: 135-146.

Recibido el 19 de diciembre de 2006 y aceptado el 28 de septiembre de 2007 